\title{
Strategic determinants of performance of family businesses in the USA and Canada
}

\section{Jooh Lee* and Niranjan Pati}

\author{
Department of Management and Entrepreneurship, \\ William G. Rohrer College of Business, \\ Rowan University, \\ 201 Mullica Hill Road, \\ Glassboro, NJ 08028, USA \\ Email: lee@rowan.edu \\ Email: pati@rowan.edu \\ *Corresponding author
}

\begin{abstract}
The research explores the relationship among accounting-based performance indices measured in terms of return on assets (ROA), return on equity (ROE), and return on investment (ROI), and market-based performance indices, Tobin's Q, market value, and sales growth in the USA and Canadian family-based businesses. Through the traditional OLS regression analysis, it was confirmed that the firm size, advertising intensity, capital intensity, current ratio, labour productivity, and the firm's age are most likely to have a significant and positive impact on marketing performance indices. Additionally, strategic factors like firm size, capital intensity, current ratio, and labour productivity are statistically significant in determining accounting-based performance measure while R\&D intensity (except ROA and ROE), debt leverage, and firm's age are not statistically significant in indicating its accounting performance. The results have a broad implication for managers in family businesses to build a competitive advantage for their organisation.
\end{abstract}

Keywords: R\&D intensity; capital intensity; advertising intensity; OLS; Tobin's Q; market value; sales growth; USA; Canada.

Reference to this paper should be made as follows: Lee, J. and Pati, N. (2020) 'Strategic determinants of performance of family businesses in the USA and Canada', Int. J. Family Business and Regional Development, Vol. 1, No. 1, pp.100-125.

Biographical notes: Jooh Lee is a Professor of Management and Entrepreneurship at the Rohrer College of Business at Rowan University, USA. $\mathrm{He}$ earned his Master's degree at Colorado State and his $\mathrm{PhD}$ at the University of Mississippi. His research focuses primarily on strategic and operational linkages between performance and strategy, particularly concerning corporate sustainability, technology capabilities, corporate reputation, and executive compensation across countries. He has published over 150 scholarly articles in 50 different refereed journals and received more than a dozen of professional accolades. He was formerly a holder of the John B. Campbell Professorial Chair at the Rohrer College of Business at Rowan University.

Niranjan Pati is a Professor of Management and Entrepreneurship at the Rohrer College of Business at Rowan University, USA. He holds his Master and PhD degrees from Northwestern University, Evanston, Illinois. Also, he holds a Master in Industrial Engineering and Operations Research from Indian Institute 
of Technology. He served as the Dean of two AACSB accredited business schools, namely, at the Rohrer College of Business, Rowan University (2008-2012) and the School of Business at Indiana University (2001-2008). He published several peer-reviewed journal articles in the areas of operations management, R\&D management, technology management, quality management, benchmarking, sustainability, and family business. He has guest-edited special issues of several journals. Currently, he serves on the editorial board of five peer-reviewed journals.

\section{Introduction}

Family businesses form a majority of profit-seeking entities worldwide (Kachaner et al., 2012). They contribute significantly to local, regional, national, and global economies. A majority of the family businesses in the USA and Canada launched their operations in traditional industries such as manufacturing, trading, and banking. They proliferated to other business sectors as opportunities arose. Their scope of operations now ranges from a few million to several billion in US dollars. Some of these firms produce household brands whereas some produce generic products. Some of these firms utilise the economy of scale and hold very few items in their product or service portfolios. At the other end of the gamut, some of these firms utilise the economy of scope to include a multitude of items in their portfolio. Notwithstanding their scale and scope, some of these family businesses have become major global players while some have chosen to be limited to domestic markets. Due to their sheer contributions to creating wealth globally, researchers have shown surging interests in the last three decades to unravel the nature of family businesses in terms of their definitions (Shanker and Astrachan, 1996; Astrachan and Shanker, 2003; Villalonga and Amit, 2006; Li and Srinivasan, 2011); Sarkar et al., 2014), ownership transfers and involvement (Chang et al., 2008; Bjuggren et al., 2011; Chirico and Salvato, 2016), innovation and entrepreneurship (Laursen and Salter, 2006; Ahuja et al., 2008; Lee et al., 2010; Zahra, 2012; König et al., 2013), performance management (Anderson and Reeb, 2003; Block et al., 2013), knowledge management (Kogut and Zander, 1992; Calantone et al., 2002; Chirico and Salvato, 2008), technology adoption (Chen et al., 2011; Block, 2012; Kotlar et al., 2013; Brinkerink and Bammens, 2018) and involvement in economic development (Basco, 2015; Stough et al., 2015; Galvan et al., 2017). The above are representative categories of research related to family businesses, and by no measure, they imply to be exhaustive.

Performance assessment of family businesses remains a central research question in contemporary business research due to the importance of these types of businesses to the overall growth of our economies. The performance of family firms involves quantitative indicators such as the ones captured by accounting and marketing-based measures. Non-quantitative measures also are explored by several researchers. There is quite a few research that use both quantitative and non-quantitative measures to build a multi-faceted construct for firm performance (Pérez-Cabañero et al., 2012; Venkatraman and 
Ramanujam, 1986). The family firm performance is partly dictated by the motivation of family managers because the success and failure of these firms are governed by how these managers (agents) pursue the organisational goals such as financial objectives, reputation, longevity, image, identity, and efficiency in resource utilisation set by the owners (principals) in tandem with their personal goals and aspirations such as career progression and their personal well-being (Anderson and Reeb, 2003; Miller and Le Breton-Miller, 2006; Chrisman et al., 2015). Due to the lack of a consensus regarding what constitutes performance and how it is measured, the issue becomes complicated and convoluted (Kim and Gao, 2013). At this juncture, our research aims to bring clarity to establish the strategic determinants that reflect on the performance of family businesses in the USA and Canada.

\section{Relevant literature}

Several studies show that the firm size is one of the most well-developed and validated determinants of a public firm's economic performance (Lee and Xiao, 2011; Wolff and Pett, 2000). Lawless et al. (2015) posit that banks are the primary source of funding for small and medium firms, while capital markets make up most of the substantial firm funding. Thus, the size of the firm changes the amount of access to capital the company has, which affects the ability of the firm to fund its growth. These differences present advantages to firms depending on their sizes, e.g., providing larger firms with an economic benefit because of wider access to external leverage.

According to Gómez-Mejía et al. (2001), variations in the size of the firm may lead to changes in decision making. The changes in the size of the company also have an impact on the mix of family and non-family managers, and firms can obtain the benefits of non-family manager specialisation without worrying about the threats as the firm grows (Fang et al., 2016). Therefore, it would make sense for family-owned firms of more substantial size have improved financial performance, as they can diversify their management pool and hire key decision makers that are highly specialised in their field. This diversification would likely lead to improved operational benefits and thus increase the profitability and performance of the overall firm.

On the other hand, Li and Zhu (2015) found that privately owned Chinese firms experienced stronger economic performance with higher family involvement in smaller companies, but the impact decreased with the size of the firm eventually leading to a negative impact on performance. Poza (2007) offers that smaller family firms can recognise their competitive advantages because they can better maintain the family-business relation that gives them the differentiation as a family-owned business. Additionally, Chu (2011) concludes that SMEs are more likely to recognise increased firm performance because of family ownership than large firms. The empirical findings of Lwango et al. (2017) display that there is an adverse moderating effect of firm size (along with firm age) on the profitability of a firm, further increasing the evidence of a negative relationship with size and profitability. From the evidence found in prior 
literature, we draw our hypothesis to align with the negative association of firm size and profitability within family-owned companies. Our study aims to evaluate the relationship between the size of a firm and its impact on economic performance in family-based businesses.

In order for a company to remain competitive amongst other firms in their industry, it is generally accepted that the company must invest in research and development (R\&D) to promote their technological innovations (Boso et al., 2013; Guarascio et al., 2016; Makrini, 2015). It is no surprise, therefore, that $R \& D$ expenditures are positively correlated with the profitability of a firm in both the current and long term (Liao and Lin, 2017). This study also adds that increases in R\&D expenditures positively impact the stock price of the firm. R\&D is found to contribute to improved performance through more competitive advantages (Kotlar et al., 2014). Further, De Simone et al. (2016) claim, however, that R\&D spending does not guarantee increased profits and that firms must maintain their $R \& D$ costs do not outweigh the benefits the intensity provides. Besides, innovation is found to be moderated by firm size, with larger firms benefitting from basic research and smaller from applied research (Belenzon and Patacconi, 2014).

In comparing innovation and processes, Classen et al. (2014) found that family SMEs tend to invest less extensively than non-family SMEs, and the family-owned SMEs have higher innovation activities than non-family institutions of similar size. Sciascia et al. (2015) explain that if only a small percentage of a family's wealth is from the firm equity, the owners will have a long-term focus and will invest more heavily in R\&D since they can bear the investment risks. Additionally, Chrisman et al. (2015) observed that family firms are less willing to invest in R\&D. Because family firms tend to be more risk-averse and lack diversity in skills, they are not as willing to innovate. However, because of their more stake in the company, family businesses may be able to benefit more than non-family businesses if they were to increase their R\&D intensity. The study by Matzler et al. (2015) found that large firms with family managers and directors are positively correlated to innovative intensity, and therefore can obtain a stronger competitive advantage and increase the profitability of the firm by deploying innovations. Another finding is that there is a curvilinear effect of family commitment on the innovation intensity of a family-owned firm, and those companies with either high or low commitments have the most robust innovation commitments (Hatak et al., 2016; Nikolov, 2017).

Kotlar et al. (2014) found that R\&D investments in family firms are made more as a result of suppliers' bargaining power than profitability goals, and indicate that family firms may overlook the benefits they could receive from R\&D expenditures because of a focus on multiple goals other than profitability (maintaining family control, etc.). Choi et al. (2015) explain that there is a negative relationship between R\&D intensity and family ownership. However, the relationship turns positive if growth opportunities are presented. It is possible that family firms invest in $R \& D$ more heavily when the loss of family control is anticipated.

Advertising is considered to be a significant strategy in contributing to the performance of a family firm. Marketing resources and marketing capabilities in a firm are found to be complementary (Ngo and O'Cass, 2012; Sridhar et al., 2014; Sun, 2014), and effective use of advertising for the firm's products and/or services can give an 
advantage to the family firm over its competition. Having such an advantage in marketing strategy would contribute to the overall economic performance of the firm. Steenkamp and Fang (2011) found the contributions of advertising to be inconsistent, with a stronger effect on performance during contraction periods than during expansion periods. The same study also found that the industry cyclicality moderates the advertising effects, with long-term, strong, and positive effects observed in highly cyclical industries and weak effects in more stable industries.

In family-owned companies, those that invest in advertising activities have an increased ROA and stock market performance over non-family firms (Nikolov, 2017). Teal et al. (2003) found that high-growth family firms allocate a more significant amount of their budget to mass advertising than their high-growth non-family counterparts. They are more likely to rely on a first-to-market and a high-quality strategy. The high level of mass advertising allows for the companies to obtain new customers while keeping their existing ones in order to continue their fast growth trajectory, leading to increased profitability. Additionally, Lewis and Reiley (2014) explain that older users are primarily influenced by advertisements to buy products. The validity of this is questionable because the study focuses on a single retailer; therefore, lacking an adequate sample size to make such a significant claim. In the case thorough research in this area confirms the above finding, it can allow family firms to focus their advertising intensity and benefit from an increase in sales, and concomitant profitability (Pucci et al., 2015). Further, Gallucci et al. (2015) explain that firms using their family brand in their marketing strategy benefit from improved sales growth.

Capital intensity as a strategic factor for a family firm is validated through performance measures (Leitch and Lamminmaki, 2011), though neither the impact nor the explanation of the factor is consistent. For example, Hecht (2008) established a negative correlation between capital intensity and profitability. On the other hand, Isik (2017) found that the capital expenditures (as a ratio to sales) are not statistically significant in term of its impact on a firm's profitability. Generally, the capital intensity of a firm measures its ability to use its assets to enhance its revenues. Businesses regarded as highly capital intensive in terms of the investments made in property, plant, and equipment relative to their total assets (Villalonga and Amit, 2010; Moser et al., 2017) must generate more revenues than non-capital intensive firms. The drive to invest in capital assets implies the inclination of a family firm to buttress its ability to deploy technology to enhance its operations. This drive helps the company lower its costs while increasing the quality of their output (Fahlenbrach, 2009; Villalonga and Amit, 2010). Despite the importance of this topic, little research has been done to establish capital intensity as a strategic factor to improve the performance of a family business.

Labour productivity is another strategic factor that explains the amount of output a company can achieve relative to employee efforts. Increases in productivity can stem from either increase in total output with a set amount of capital invested in labour, or from a decrease in the cost to produce the same amount of output. Firms with low efficiency in their labour have low profitability in general (Golas, 2011). Fabling and Grimes (2014) concluded that better human resource management (HRM) practices provide a positive impact on the labour productivity of a firm, especially in manufacturing industries and higher level professional services. 
Despite the positive relationship between the productivity and profitability of a firm, lower productivity is often found in family firms because they have difficulty in attracting the best candidates from the labour market (Chrisman et al., 2017). Further, family firms might have retaining the best employees as they are less likely than non-family firms to use incentive-based pay (Memili et al., 2013). Greer et al. (2016) found that recruiting practices to increase the performance of a firm in terms of labour productivity. Therefore, our literature survey indicated that family firms should focus their attention on improved labour productivity through hiring and training. If this relationship holds valid, firm performance will increase as a result of the increase in labour productivity.

Debt leverage is one of the important factors in strategy decisions, but it is a double-edged sword. While the use of debt to finance a firm's operation can vastly improve its performance, it makes the firm riskier because of the increase of debt. If the firm is not able to leverage the debt to earn profits, it can fall behind in meeting its obligations which can throw the company in a downward spiral to progressively increase losses. An increased level of debt may bring a few tax advantages to a firm. However, there is an optimum level of leverage that allows the firm to most efficiently operate (Kane et al., 1985). Kazempour and Aghaei (2015) explain that there is a positive and significant correlation between the capital structure measured through debt leverage and firm performance. Provided a firm's debt leverage is adequately financed, it may increase profitability.

Further, Yildirim (2015) noted that it is better to focus on the change in leverage than leverage itself as an indicator of a firm's growth. In contrast, Zelgalve and Berzkalne (2015) argued that the size of the firm and the type of debt have a bearing on a firm's growth. Their study indicated that larger firms have a less-negative relationship between profitability and debt. Further, they found that short-term debts are more likely to decrease profitability than long-term debts. The finding that larger firms react more favourably to debt affirms that debt is a necessary factor to support growth. This is due to the reason that large firms need additional access to capital than the small firms as equity financing becomes more and more expensive in that situation. It was also found that firms with greater leverage experience significantly reduced performance when compared to the competition in economic duress (Gonzalez, 2013). Further, Strebulaev and Yang (2013) found that firms with zero or near-zero leverage that pays dividends to have larger cash balances and are more profitable despite higher tax burden. This phenomenon is not explained by the size of the firm and the type of industry. In the context of family-owned firms, van Essen et al. (2014) found that they are more conservative when choosing financial structures, and therefore prefer less leverage than non-family firms (Nguyen et al., 2013). This modus operandi allows family firms to maintain control of their company and utilise equity financing to avoid conflict with external financing entities (Colot and Croquet, 2009).

The capital structure of a family firm is guided by whether it uses debt or equity and internal or external financing predominantly (Hovakimian et al., 2001; López-Gracia Sánchez-Andújar, 2007; Madashetti and Kibona, 2013; Shin et al., 2015). One of the essential drivers of the capital structure is the current ratio which is defined by the ratio of current assets to current liabilities. The ratio ascertains the liquidity of a firm. A high current ratio indicates the ability of a firm to meet its short term resource needs (Romano et al., 2001; Zainudin and Regupathi, 2010; Wang, et al., 2015). The financial risk of a 
firm is directly associated with its capital structure which is measured by the ratio of debt to equity (Leitch and Lamminmaki, 2011). Family firms are more likely to engage in risk aversion strategies and utilise lower debts compared to non-family firms. They maintain a higher level of liquidity to mitigate the risk associated with the loss of family control (Zainudin and Regupathi, 2010, Bigeli and Sánchez-Vidal, 2012; Malik and Bukhari, 2014; Ma et al., 2017). Colot and Croquet (2009) established that the long term debt of family businesses tend to be higher than their non-family counterpart.

In the studies of performance of family firms, the age of the firm has often been used as a control variable (Girma et al., 2004; Fryges and Wagner, 2010; Kneller and Pisu, 2010; Larimo, 2013; Kim and Gao, 2013; Cucculelli et al., 2014; Lu et al., 2015). However, several studies relate firm's age to strategic choices family firms pursue to improve their performance (Sorensen and Stuart, 2000; Jovanovic, 2001; Levesque and Minniti, 2006; Marshall et al., 2006; Minetti et al., 2015). While firm performance solidifies over the age due to implementation of productive processes and adoption of new technologies (Cohen and Levinthal, 1990; Pakes and Ericson, 1998; Acemoglu et al., 2006; Bloom et al., 2008), some firms show inflexibility, inertia, and risk aversion as they age (Leonard-Barton, 1992; Hall et al., 2001; Agarwal and Gort, 2002; Miller and Shamsie, 2001; Demirhan (2016). Aging of some family firms manifests in passive learning which makes them learn from their mistakes when they stay in business long enough (Gómez-Mejía et al., 2001, 2007; Carney, 2005; Tsao and Lien, 2013). On the contrary, there are many family firms that pursue active learning, i.e., the act of learning by doing (Geroski, 1995; Balasubramanian and Lieberman, 2010; Park et al., 2010; Esteves and Rua, 2015). The literature is, thus, ambivalent about the influence of age on family firms.

\section{Research hypotheses}

The preceding discussion leads to several hypotheses relative to family firms operating in the USA and Canada.

$\mathrm{H}_{1} \quad$ The size of the firm is significantly and positively associated with its performance.

$\mathrm{H}_{2} \quad \mathrm{R} \& \mathrm{D}$ intensity is significantly and positively associated with the firm performance.

$\mathrm{H}_{3} \quad$ Advertising intensity is significantly and positively associated with the firm performance.

$\mathrm{H}_{4}$ Capital intensity is significantly and positively associated with the firm performance.

$\mathrm{H}_{5}$ Debt leverage is significantly and negatively associated with the firm performance.

$\mathrm{H}_{6}$ Current ratio is significantly and positively associated with the firm performance.

$\mathrm{H}_{7}$ Labour productivity is significantly and positively associated with the firm performance.

$\mathrm{H}_{8} \quad$ Firm's age is significantly and positively associated with firm performance. 


\section{Research method}

\subsection{Samples and data collection}

We collected the data for this empirical research from 2017 Global Family Business Index which covers the rankings of the top 500 largest businesses that have a minimum of $32.5 \%$ control by a single family (http://familybusinessindex.com). The preceding link also mentions 'For a privately held firm, a firm is classified as a family firm in case a family controls more than $50 \%$ of the voting rights. For a publicly listed firm, a firm is classified as a family firm in case the family holds at least $32 \%$ of the voting rights'. In order to be consistent, we focused on the US and Canadian firms. Further, we excluded finance-related firms (SIC 6000-6999) and government and special service related firms (SIC 9000-9999) because of their different accounting structure in performance measures. Due to the availability of data, a total of 105 firms were finally selected for this study (see Table 1). The data for various performance variables and other explanatory variables employed in this study were taken from the Research Insight and Capital IQ for the period 2011 through 2015 (see Table 1). We employed a five-year aggregated average value because the sample is a quasi-panel dataset and had missing values for some firms and years. A five-year data period was chosen to avoid any possible issues that may be associated with one-year fluctuation. Aggregated averages were used to minimise the potential effect of any outliers or idiosyncratic variations (Lee and Hall, 2008). Family firms with reasonably reliable data over the years were selected to ensure comparability across different models across different performance measure used in this research.

\subsection{Description and measurement of performance variables}

The following exogenous and endogenous variables were selected to explore the effects of selected strategic factors on a family firm's economic performance concerning both market- and accounting-based measures. As stated before, most previous empirical studies on the family firm's performance have focused on the use of accounting and/or finance-based performance. Although accounting-based measures are historical and have been the primary focus of much of the past empirical research (Tallman and Li, 1996), we incorporated market-based measures of performance to reflect the market's perceptions of future performance (Dubofsky and Varadarajan, 1987; Michel and Shaked, 1984). As accounting-based measures of performance reflect the past year's earnings and market-based measures of performance reflect the market's perceptions of future earnings as financial sources for sustainable growth, the hybrid of the two streams of performance can be expected to do an excellent job of benchmarking the overall performance of a family firm. In order to gain a more accurate assessment of firm performance and to minimise possible weaknesses associated with the use of any single performance measure, this study considered the various indices of performance measures attributed to accounting-based and market-based performance. 
Table 1 Descriptive statistics for selected variables by industry affiliation

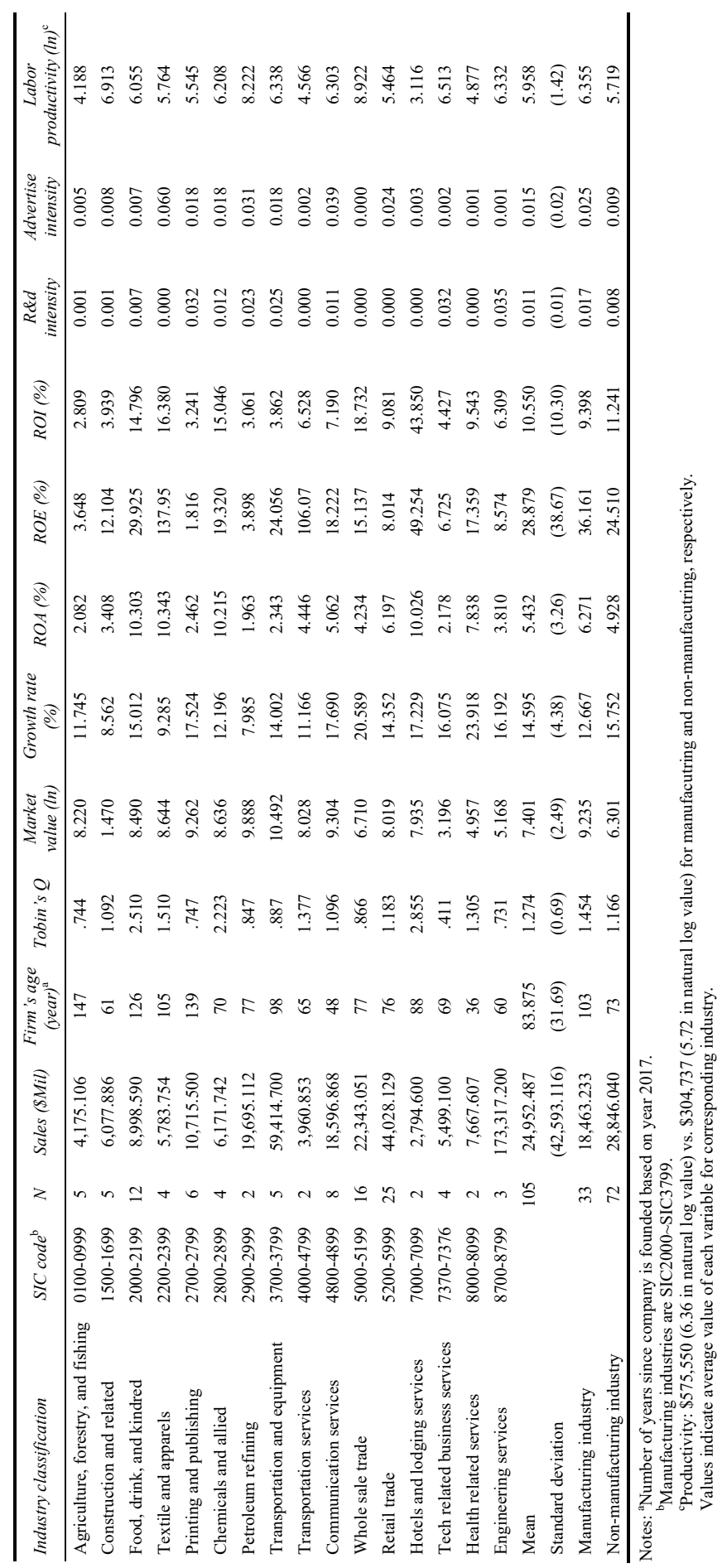




\subsection{Accounting-based performance}

Accounting-based performance is based upon the firm's balance sheet and income statement. As presented in the variable measurement, return on assets (ROA) indicates the firm's ability to utilise its assets to create profits. Return on equity (ROE) signifies how well the firm is maximising shareholder's wealth based on the book value of shareholders' equity, not the market value. Return on investments (ROI) indicates what percent of the firm's capital investment contribute to net income. More specifically, they are measured quantitatively by the following ratios.

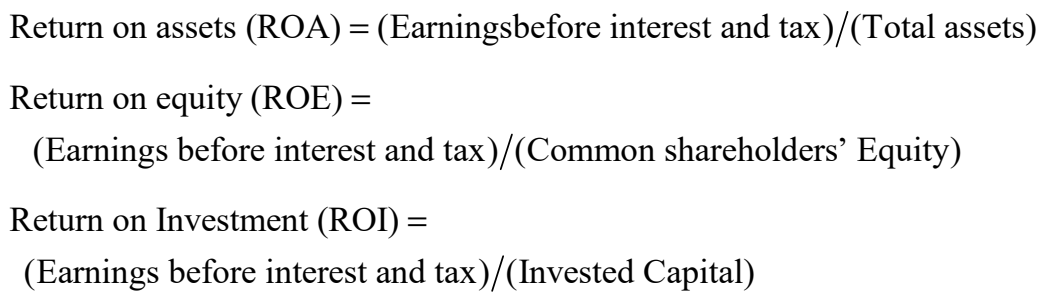

\subsection{Market-based performance}

In addition to using accounting-based indices, three market-based performance measures were used to assess the investors' expectations about the future profit such as:
1 Tobin's Q
2 market value
3 sales growth.

Tobin's $Q$ is a measure of the growth prospects of the firm, and the rents form more long-term or tangible assets. As one of the most representative market-based performance measures, Tobin's $Q$ is defined as the ratio of the market values of the firm (i.e., the present value of future cash flows) to the replacement cost of its tangible assets (Lang and Stulz, 1994). Q value below 1 (price less than replacement book value) implies that the firm earns less than the required rate of return. Alternatively, a (marginal) dollar invested in the firm's assets results in future cash flows whose present value is less than $\$ 1$. Such firms are poor performers. Compared to stock returns in accounting performance, Tobin's Q does not require risk adjustment as well as normalisation.

$$
\begin{aligned}
\text { Tobin's } \mathrm{Q}= & \text { (Market value of shareholder's equity } \\
& + \text { Liquidating value ofthe firm's outstanding preferred stock } \\
& + \text { Book value of total debts }) /(\text { Bookvalue of total assets })
\end{aligned}
$$

In this context, market value is the amount a firm could be sold as a continuing operating business in the stock market. It also indicates the firms operating power to generate positive cash flows to security investors in determining the value of the firm's financial securities. Managers and investors will frequently be interested in knowing the value of 
the firm because of its going-concern value rather than its liquidation value (i.e., amount of money that could be realised if an asset or a group of assets is sold separately from its operating organisation). Market value is measured by the product of the fiscal year end of stock price and the total outstanding shares.

$$
\begin{aligned}
\text { Market value } & =\operatorname{Ln}(\text { Year }- \text { endclosing stock price }) \\
& *(\text { Common shareholders' outstanding shares })
\end{aligned}
$$

Sales Growth is a good indicator of how quickly the sales revenues for the company's products are growing compared to the prior period.

$$
\text { Sales Growth }=\left[\operatorname{Sales}_{(\mathrm{t})}-\operatorname{Sales}_{(\mathrm{t}-1)}\right] / \operatorname{Sales}_{(\mathrm{t}-1)}
$$

\subsection{Selected strategic explanatory variables}

The following key explanatory variables were employed in this study in order to explore the potential strategic determinants of the family firms' economic performance. The explanatory variables incorporated in this study are,

1 firm size

2 capital intensity

3 R\&D intensity

4 advertising intensity

5 debt leverage

6 current ratio

7 labour productivity

8 firm's age.

More specifically,

1 Firm size is used to indicate a firm's competitive power and economies of scales in a given industry.

2 Capital intensity is used to measure a firm's efficiency in deployment of its assets for operational processes.

$3 R \& D$ intensity is used to measure a firm's innovation efforts in products and services.

4 Advertising intensity is used to demonstrate a firm's products and services to the consumers.

5 Debt leverage is used to measure a firm's sound capital budgeting. 
6 Current ratio is used to measure a firm's ability to pay back its short-term financial obligations.

7 Labour productivity indicates the efficiency of an average worker for sales revenue.

8 Firm's age indicates the firm's historical business experience since the firm was established. It was measured by the number of years since the firm was established.

Besides, one dummy variable (manufacturing vs. non-manufacturing) was employed to investigate the influence of different types of industries on performance. Each of the above variables was operationalised in the following manner.

- $\quad$ firm size $=$ natural log value of total sales (us\$-based)

- $\quad$ capital intensity $=$ total assets $/$ total sales

- debt leverage = book value of total debt / shareholder's equity

- $\quad$ current ratio $=$ current assets $/$ current liabilities

- $\quad$ labour productivity = sales (US\$) / number of employees

- $\quad \mathrm{R} \& \mathrm{D}$ intensity $=\mathrm{R} \& \mathrm{D}$ expenditure / total sales

- $\quad$ advertising intensity $=$ advertising expenses / total sales

- $\quad$ firm's age = no. of periods (years) since firm is established (as of 2016)

- industry dummy: manufacturing (1) vs. service (0).

We included the above set of variables because, we believe, these are the most relevant strategic factors that affect the performance in family-oriented firms. Our survey of current literature further reinforced our conviction.

\section{Empirical model}

We employed the traditional OLS multiple regression analysis to investigate the effect of selected strategic determinants on a firm's multidimensional performance, namely, accounting and market performance. We were convinced that the OLS multiple regression is a powerful technique to uphold or refute the assertions made in our hypotheses.

The specific empirical model is as follows:

EconomicPerformance (Accounting-based and Market-based Performance $)=$

$\alpha_{0}+\beta_{1}$ Firm size $+\beta_{2}$ R\&D intensity $+\beta_{3}$ Advertising intensity

$+\beta_{4}$ Capital intensity $+\beta_{5}$ Debt leverage $+\beta_{6}$ Current ratio $+\beta_{7}$ Labour productivity

$+\beta_{8}$ Firm's age $+\beta_{9}$ INDSTRY $+\varepsilon$ 


\section{Empirical analysis and major findings}

As presented in Table 1, the sample employed in this study was adequate to generalise the empirical results in light of the limited number of databases available for family-oriented businesses. The means and standard deviations of all performance variables including selected strategic determinants are presented in Table 1. The non-manufacturing firms show relatively higher means $(\$ 28,846,040)$ than non-manufacturing firms $(\$ 18,463,233$ in terms of total sales revenues during the period under study. However, manufacturing firms showed higher market performance than non-manufacturing firms in 2 out of 3 measures: Tobin's Q (1.454 vs. 1.166) and ln of market value (9.235 vs. 5.301). In the criterion of sales growth, non-manufacturing firms fared better with $15.752 \%$ compared to manufacturing firms' $12.667 \%$. Regarding accounting performance, the manufacturing firms group performed better than the non-manufacturing group in ROA (6.271\% vs. 4.928\%) and ROE (36.161\% vs. 24.51\%). Non-manufacturing firms led only in ROI (11.241\% vs. 9.398\%). As expected, manufacturing firms invested more in both $\mathrm{R} \& \mathrm{D}(1.7 \%)$ and advertising $(2.5 \%)$ compared to the non-manufacturing firms $(0.8 \%$ and $0.9 \%$, respectively). The labour productivity in manufacturing sector converted from $\ln$ to normal values $(\$ 575,550)$ is considerably higher than the non-manufacturing sector $(\$ 304,737)$ based on the total number of employees (both full-time and part-time). The labour productivity in the non-manufacturing industry sectors is likely to be concentrated in wholesale trade firms while petroleum refining led the pack in the manufacturing sector.

Table 2 presents the intercorrelations among variables employed, the performance measures, and selected strategic factors. The table also presents their means and standard deviations. Although we applied the exclude case list-wise method in treating missing values, i.e., only cases with valid values for all variables were included in the analysis, the impact of selected explanatory variables on firm performance varied depending on which performance measures are being considered. First of all, capital intensity shows a positive correlation with all marketing-based and accounting-based indicators at least at a significance level of 0.05 or lower. Firm size and advertising intensity show a positive correlation with marketing and accounting-based indicators except for ROE at a significance level of 0.05 or lower. Labour productivity and firm's age are highly correlated with marketing-based performance measures, i.e., Tobin's Q, market value, and Growth rate in sales, at the 0.05 level of significance. Interestingly, R\&D intensity is more likely to be significantly and positively correlated with market-based performance (except market value) and return on investment (ROI) only.

Thus, the impact of the strategic factors on performance seems to vary across different indices of firm economic performance. However, firm size, advertising intensity, capital intensity, labour productivity, and firm's age tend to be uniformly and positively correlated with mostly market-based performance measures. On the other hand, the firm size (except ROE), is positively correlated with accounting-based performance. In particular, capital intensity and current ratio that is used to measure a firm's financial liquidity to cover its obligations appear to be uniformly and positively correlated with all accounting-based performance indicators included in this research. 
Table 2 Descriptive statistics and correlations

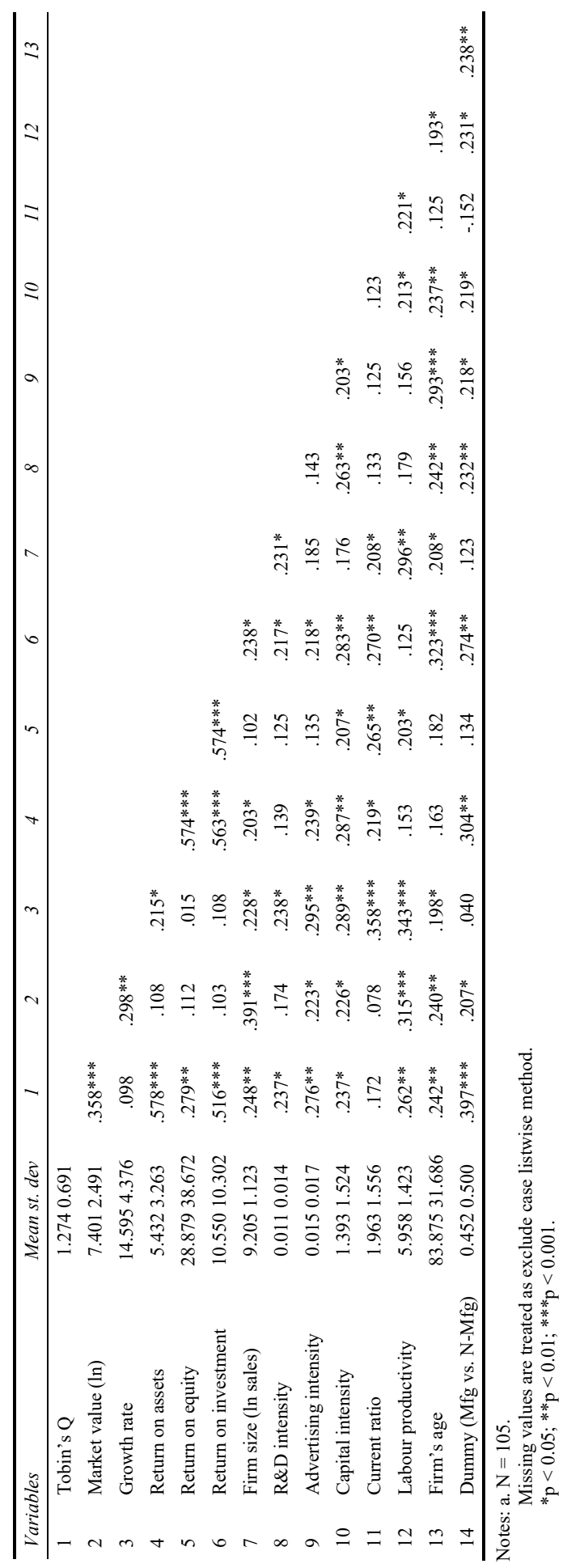




\section{Traditional OLS multiple regression analysis}

In an attempt to further explore the strategic determinants of firm economic performance concerning both market-based (Tobin's q, market value, and compound growth rate in sales) and accounting-based performance (ROA, ROE, ROI) measures, the traditional OLS multiple regression analysis was utilised. The analysis was utilised to provide information on which factors can be used as significant determinants of firm performance individually. The results of the multiple regression analysis are contained in Table 3 (market-based performance) and Table 4 (accounting-based performance). Before we proceeded with this analysis, we first checked the existence of the collinearity problem which could hinder our regression analysis. As presented in Tables 3 and 4, there was no evidence of multicollinearity because all variance inflation factors (V.I.F.) in overall models were between 1.052 and 3.112.

Concerning market-based performance presented in Table 3, the employed model is enough to explain potential strategic determinants with $R^{2}$ values between 0.4558 and $0.5204, R^{2}$ adj between 0.3012 and 0.4699 , and $F$-value between 12.523 and 15.306 , $p<0.001$ in all models). Thus, most models accounted for almost $45.59 \%$ to $52.04 \%$ of the variance in market-based performance. As would be expected, the results confirm that the firm size, advertising intensity, capital intensity, current ratio, labour productivity, and firm's age are most likely to have a significant and positive impact of most market performance measures and are important explanatory factors in predicting market performance. Although the effects of firm performance and selected factors showed some variations in its significance, it should be noted that the overall effect of selected factors except debt leverage and $R \& D$ intensity (except for market value) on market-based performance were significant $(p<0.05)$. Likewise, the employed strategic determinants employed in the model can predict the account-based performance measures as evidenced in Table 4 with $R^{2}$ between 0.3521 and $0.4653, R_{\text {adj }}^{2}$ between 0.2945 and 0.3785 , and $F$-value between $9.856 \sim 13.495$, and $p<0.001$ in all models). Table 4 further shows that some strategic factors such as the firm size, capital intensity, current ratio, and labour productivity are statistically significant in determining accounting performance measures. These results go hand in hand with the outcome of the marketing-based performance measures. Interestingly, R\&D intensity (except ROA and ROE), debt leverage, and firm's age were not statistically significant in determining accounting performance measures. As for the industry factor in determining firm performance, there were significant differences between manufacturing and non-manufacturing industries in both performance measures. 
Table 3 Results of OLS multiple regression analysis: market-based performance ${ }^{a}$

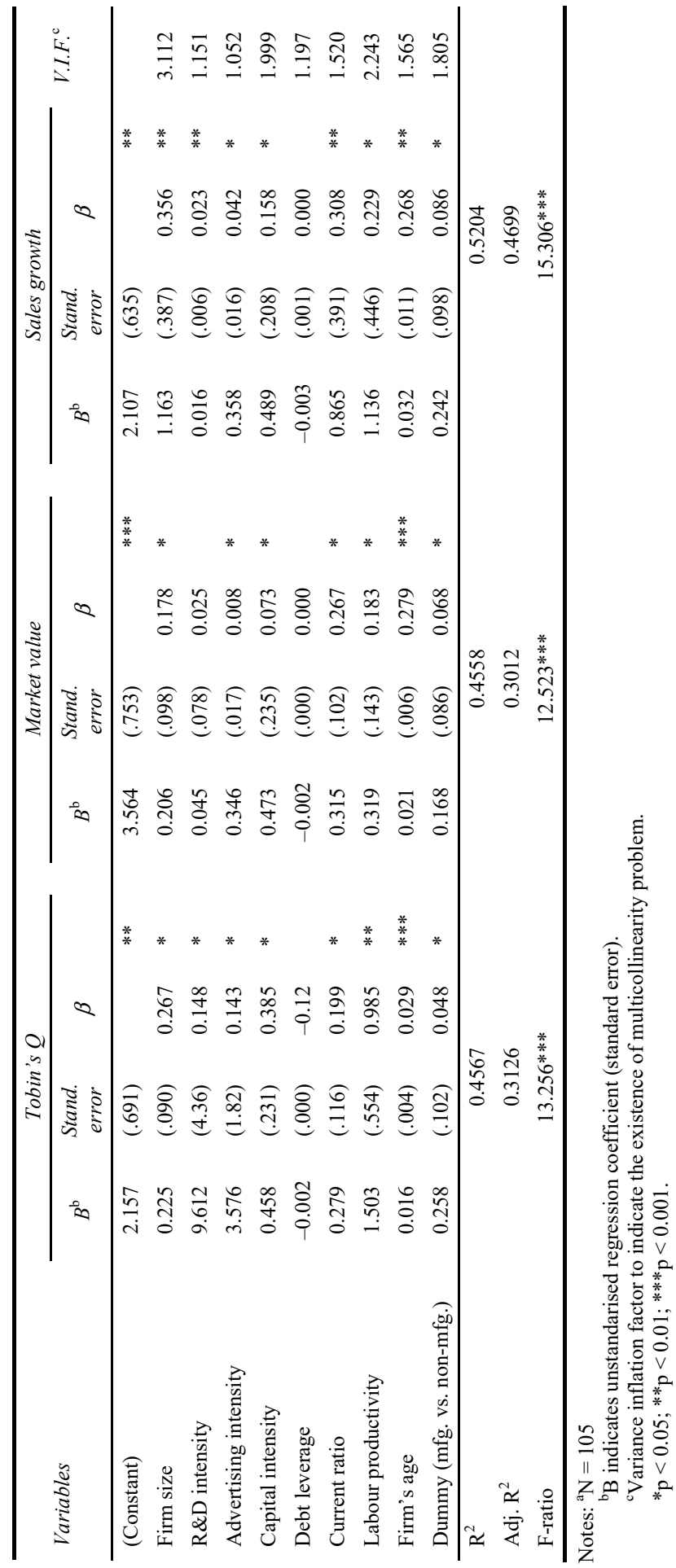


Table 4 Results of OLS multiple regresssion analysis: accounting-based performance ${ }^{\mathrm{a}}$

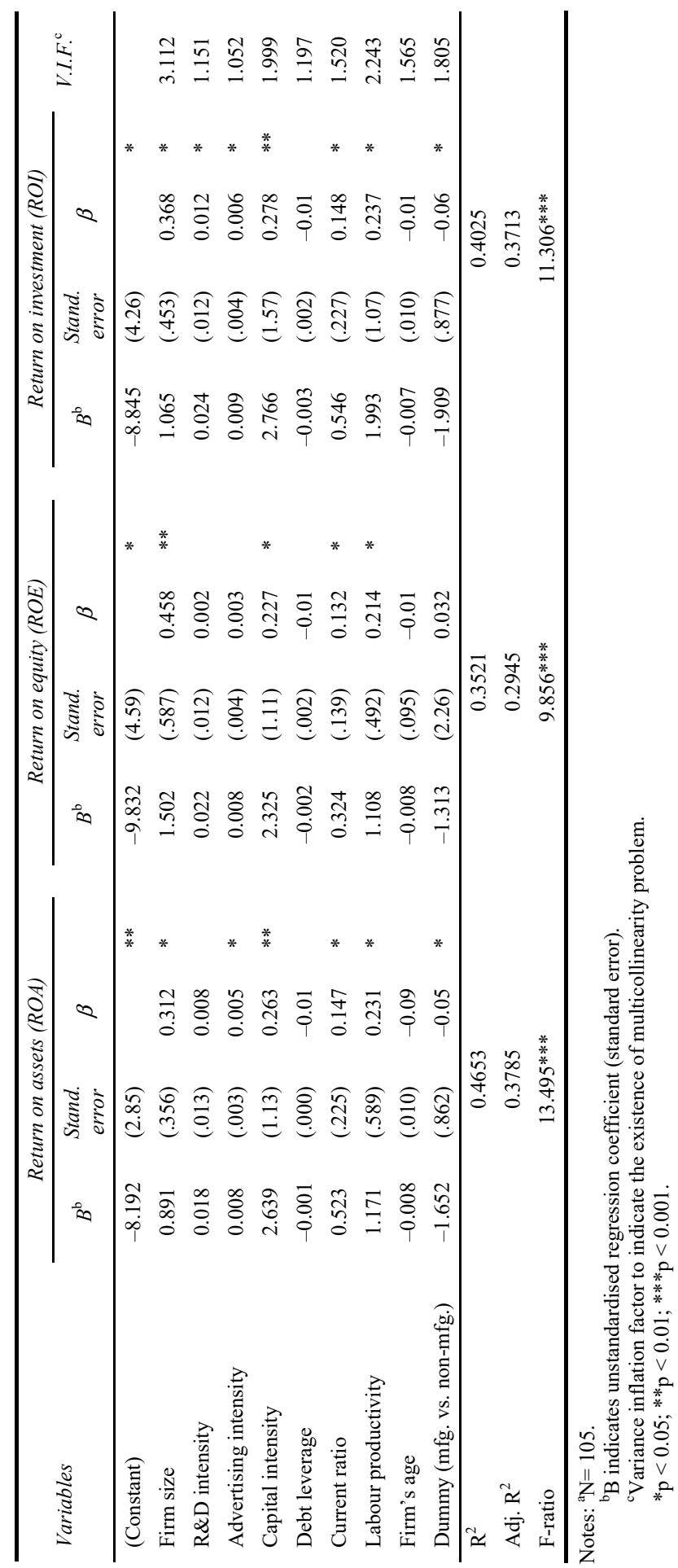


As hypothesised, firm size, capital intensity, current ratio, labour productivity, and advertising intensity (except for ROE) are most likely to be the significant strategic determinants of the family firm performance regardless of performance measures employed in family-based businesses. However, other factors like R\&D intensity, debt leverage, and the firm's age seemed to be used as vital strategic factors in determining firm performance depending on which performance measures are being strategically facilitated. For instance, while debt leverage is not statistically significant on both performance measures, the firm's age bears significance for the market-based performance but not for the accounting-based performance. The R\&D intensity has significance for a part of the market-based indicator, i.e., Tobin's Q and Sales Growth (at least at $p<0.05$ ), and a part of the accounting-based indicator, i.e., Sales Growth (at $p<0.05$ ). Thus, it is implied that any single or couple of performance measures, if employed to explore strategic factors, may not be enough to yield optimal results. Considering all the above results into account, the inference could be made that some selected explanatory factors cannot be considered as significant strategic determinants consistently. Even though there may be some arguments in justifying the generalisability of performance measures, our research strongly supports that our selected strategic factors (e.g., firm size, R\&D intensity, adverting intensity, capital intensity, current ratio, labour productivity, and even the firm's age) are most likely to be used as robust and significant factors in most accounting-based measures (ROA, ROE, and ROI) and market-based performance measures (Tobin's Q, Market value, and Sales Growth) in family-oriented businesses.

\section{Conclusions and implications}

The purpose of this study was to empirically examine the nature of the influence of the strategic determinants on the economic performance relative to accounting-based and market-based performance measures in the leading US and Canadian family-oriented firms. The main questions addressed in this paper relate to

1 the impact of strategic determinants that are traditionally studied in business and management literature on various dimensions of firm performance measures

2 and the generalisability of the strategic relationships between selected strategic factors and firm performance across different industries.

Notably, this study explored the directions and magnitudes of vital strategic factors, such as the firm size, R\&D intensity, advertising intensity, labour productivity, and firm's age on the firm's economic performance with respect to diverse indices of performance measures such as accounting (ROE, ROA, and ROI) and market-based performance (Tobin's Q, market value, and sales growth).

More specifically, this study has attempted to explore the existence of linkages between a selected set of strategic variables and economic performance measures, and determine the relative importance various business strategies individually for improving business performance in the family-based businesses. Further, the research empirically examined the validity and applicability of the general findings previously posited by other studies that have predominantly relied on the sample of publicly listed large firms. Although there are some differences in the direction, the results of the study indicate that 
R\&D and marketing activities can be viewed as one of the major determinants for improving competitive performance in the family-oriented firms.

Table 5 Summary of significant strategic determinants of firm performance

\begin{tabular}{|c|c|c|c|c|c|c|}
\hline \multicolumn{7}{|c|}{ Market-based performance } \\
\hline Strategic factors & \multicolumn{2}{|c|}{ Tobin's $Q$} & \multicolumn{2}{|c|}{ Market value } & \multicolumn{2}{|c|}{ Sales growth } \\
\hline Firm size & + & $*$ & + & $*$ & + & ** \\
\hline R\&D intensity & + & * & $+\mathrm{ns}$ & & + & ** \\
\hline Advertising intensity & + & $*$ & + & $*$ & + & $*$ \\
\hline Capital intensity & + & $*$ & + & $*$ & + & $*$ \\
\hline Debt leverage & - & ns & $-n s$ & & $-\mathrm{ns}$ & \\
\hline Current ratio & + & $*$ & + & * & + & $* *$ \\
\hline Labour productivity & + & $* *$ & + & $*$ & + & * \\
\hline Firm's age & + & $* * *$ & + & $* * *$ & + & $* *$ \\
\hline \multicolumn{7}{|c|}{ Accounting-based performance } \\
\hline Strategic factors & \multicolumn{2}{|c|}{$R O A$} & \multicolumn{2}{|c|}{$R O E$} & \multicolumn{2}{|c|}{$R O I$} \\
\hline Firm size & + & $*$ & + & $* *$ & + & * \\
\hline R\&D intensity & + & ns & + & $\mathrm{ns}$ & + & * \\
\hline Advertising intensity & + & $*$ & + & ns & + & $*$ \\
\hline Capital intensity & + & $* *$ & + & $*$ & + & $* *$ \\
\hline Debt leverage & $-\mathrm{ns}$ & & - & ns & $-\mathrm{ns}$ & \\
\hline Current ratio & + & $*$ & + & $*$ & + & * \\
\hline Labour productivity & + & $*$ & + & $*$ & + & $*$ \\
\hline Firm's age & $-\mathrm{ns}$ & & - & ns & - & $\mathrm{ns}$ \\
\hline
\end{tabular}

Notes: $* p<0.05 ; * * p<0.01 ; * * * p<0.001$. ns: not significant at the $5 \%$.

The motivation for this study initially stems from an interest of whether traditionally employed strategic factors can be equally used to determine the firm's performance concerning market-based in the family-oriented business. The study of competitive dynamics in the family business sectors are scarce until now. This scarcity especially is true in the case of the association of strategic factors by different corporate functions within business organisations and its constituents, with various firm performance measures. This paper investigates a multidimensional aspect of strategic resources for family firm performance in order to promote business sustainability in today's competitive market. The empirical results of this study and exploratory relationships are summarised in Table 5.

Moreover, the emphasis of this study to support these relationships in general terms may be relatively comprehensive because it employs potential strategic factors for various firm performance measures independently rather than hinging on a single measure of financial profitability. The significance of each of the selected strategic factors will be different according to the various indices of financial performance pursued by a family firm. 
As is true with all empirical studies, there are limitations of the present study that may have altered the results in an unplanned way. One limitation is that the results reported may have been biased by both a selected sample and insufficient sample firms across different industries. Moreover, the present study only looked at an aggregated firm setting with some missing values extracted from limited databases, particularly constrained by the type of family firms. A more extensive longitudinal database with inclusion of more firms, if available, may uncover other significant findings particularly concerning the strategic significance of $R \& D$ and advertising intensity on firm performance. Notwithstanding these limitations, this study offers some insightful directions to beaconflash further studies. Finally, more advanced statistical methods will provide better insightful findings and shed lights on other aspects of the studies.

Nevertheless, the significant findings of the present study will be of great importance because it not only identifies the key strategic elements that lead to success in diverse economic contexts, but it also is useful for managers in determining the appropriateness of a specific competitive strategy employed, particularly in family-oriented businesses. Additionally, this study provides the decision makers responsible for managing the family-oriented business with a better understanding of strategic resources and performance relationships across countries. In sum, this study has attempted to provide the family-oriented firms with the strategic directionsthey need, to harness operating synergies while buttressing economic performance by allocating the scarce resources available to them with orchestrated strategies.

\section{References}

Acemoglu, D., Aghion, P., Lelarge, C., Reenen, J.V. and Zilibotti, F. (2006) Technology, Information and the Decentralization of the Firm, NBER Working Paper No. 12206.

Agarwal, R. and Gort, M. (2002) 'Firm and product life cycles and firm survival', American Economic Review, Vol. 92, No. 2, pp.184-190.

Ahuja, G., Lampert, C.M. and Tandon, V. (2008) 'Moving beyond Schumpeter: management research on the determinants of technological innovation', Academy of Management Annals, Vol. 2, No. 1, pp.1-98.

Anderson, R.C. and Reeb, D.R. (2003) 'Founding-family ownership and firm performance: evidence from the S\&P 500', The Journal of Finance, Vol. 58, No. 3, pp.1301-1328.

Astranchan, J.H. and Shanker, M.C. (2003) 'Family businesses' contribution to the U.S. economy: a closer look', Family Business Review, Vol. 16, No. 3, pp.211-219.

Balasubramanian, N. and Lieberman, M.B. (2010) 'Industry learning environments and the heterogeneity of firm performance', Strategic Management Journal, Vol. 31, No. 4, pp.390-412.

Basco, R. (2015) 'Family business and regional development - a theoretical model of regional familiness', The Journal of Family Business Strategy, Vol. 6, No. 4, pp.259-271.

Belenzon, S. and Patacconi, A. (2014) 'How does firm size moderate firms' ability to benefit from invention? Evidence from patents and scientific publications', European Management Review, Vol. 11, No. 1, pp.21-45.

Bigeli, M. and Sánchez-Vidal, J. (2012) 'Cash holdings in private firms', Journal of Banking \& Finance, Vol. 36, No. 1, pp.26-35.

Bjuggren, C.M., Johansson, D. and Sjögren, H. (2011) 'A note on employment and gross domestic product in Swedish family-owned businesses: a descriptive analysis', Family Business Review, Vol. 24, No. 4, pp.362-371. 
Block, J. (2012) 'R\&D investments in family and founder firms: an agency perspective', Journal of Business Venturing, Vol. 27, No. 2, pp.248-265.

Block, J., Miller, D., Jaskiewicz, P. and Spiegel, F. (2013) 'Economic and technological importance of innovations in large family and founder firms: an analysis of patent data', Family Business Review, Vol. 26, No. 2, pp.180-199.

Bloom, N., Sadun, R. and Van Reenen, J. (2008) 'Measuring and explaining management practices in Italy', Rivista Di Politica Economica, Vol. 98, No. 2, pp.15-56.

Boso, N., Story, V.M., Cadogan, J.W., Micevski, M. and Kadic-Maglajlic, S. (2013) 'Firm innovativeness and export performance: Environmental, networking, and structural contingencies', Journal of International Marketing, Vol. 21, No. 4, pp.62-87.

Brinkerink, J. and Bammens, Y. (2018) 'Family influence and R\&D spending in Dutch manufacturing SMEs: the role of identity and socioemotional decision considerations', Journal of Product Innovation Management, Vol. 35, No. 4, pp.588-608.

Calantone, R.J., Cavusgil, S.T. and Zhao, Y. (2002) 'Learning orientation, firm innovation capability, and firm performance', Industrial Marketing Management, Vol. 31, No. 6, pp.515-524.

Carney, M. (2005) 'Corporate governance and competitive advantage in family-controlled firms', Entrepreneurship Theory and Practice, Vol. 29, No. 3, pp.249-265.

Chang, E.P.C., Chrisman, J.J., Chua, J.H. and Kellermanns, F.W. (2008) 'Regional economy as a determinant of the prevalence of family firms in the United States: a preliminary report', Entrepreneurship Theory and Practice, Vol. 32, No. 3, pp.559-573.

Chen, J., Chen, Y. and Vanhaverbeke, W. (2011) 'The influence of scope, depth, and orientation of external technology sources on the innovative performance of Chinese firms', Technovation, Vol. 31, No. 8, pp.362-373.

Chirico, F. and Salvato, C. (2008) 'Knowledge integration and dynamic organizational adaptation in family firms', Family Business Review, Vol. 21, No. 1, pp.169-181.

Chirico, F. and Salvato, C. (2016) 'Knowledge internalization and product development in family firms: when relational and affective factors matter', Entrepreneurship Theory and Practice, Vol. 40, No. 1, pp.201-229.

Choi, Y.R., Zahra, S.A., Yoshikawa, T. and Han, B.H. (2015) 'Family ownership and R\&D investment: the role of growth opportunities and business group membership', Journal of Business Research, Vol. 68, No. 5, pp.1053-1061.

Chrisman, J.J., Chua, J.H., De Massis, A., Frattini, F. and Wright, M. (2015) 'The ability and willingness paradox in family firm innovation', Journal of Product Innovation Management, Vol. 32, No. 3, pp.310-318.

Chrisman, J.J., Devaraj, S. and Patel, P.C. (2017) 'The impact of incentive compensation on labor productivity in family and nonfamily firms', Family Business Review, Vol. 30, No. 2, pp.119-136.

Chu, W. (2011) 'Family ownership and firm performance: Influence of family management, firm control, and firm size', Asia Pacific Journal of Management, Vol. 28, No. 4, pp.833-851.

Classen, N., Carree, M., Van Gils, A. and Peters, B. (2014) 'Innovation in family and non-family SMEs - an exploratory analysis', Small Business Economics, Vol. 42, No. 3, pp.595-609.

Cohen, W.M. and Levinthal, D. (1990) 'Absorptive capacity: a new perspective on learning and innovation', Administrative Science Quarterly, Vol. 35, No. 1, pp.128-152.

Colot, O. and Croquet, M. (2009) 'Debt of family firms: a comparison based on accounting indicators', Corporate Ownership \& Control, Vol. 6, No. 3, pp.53-60.

Cucculelli, M., Mannarino, L., Pupo, V. and Fernanda R. (2014) 'Owner-management, firm age, and productivity in Italian family firms', Journal of Small Business Management, Vol. 52, No. 2, pp.325-343. 
De Simone, L., Jing, H. and Krull, L. (2016) Foreign Profitability and the Rising Foreign R\&D of U.S. Multinational Corporations, pp.1-49, Working Papers (Faculty) - Stanford Graduate School of Business.

Demirhan, A.A. (2016) 'To be exporter or not to be exporter? Entry-exit dynamics of Turkish manufacturing firms', Empirical Economics, Vol. 51, No. 1, pp.181-200.

Dubofsky, P. and Varadarajan, P. (1987) 'Diversification measures of performance: additional empirical evidence', Academy of Management Journal, Vol. 30, No. 3, pp.597-608.

Esteves, P. and Rua, A. (2015) 'Is there a role for domestic demand pressure on export performance?', Empirical Economics, Vol. 49, No. 4, pp.1173-1189.

Fabling, R. and Grimes, A. (2014) 'The 'suite' smell of success: Personnel practices and firm performance', Industrial and Labor Relations Review, Vol. 67, No. 4, pp.1095-1126.

Fahlenbrach, R. (2009) 'Founder-CEOs, investment decisions, and stock market performance', Journal of Financial and Quantitative Analysis, Vol. 44, No. 2, pp.439-466.

Fang, H., Randolph, R. V., Memili, E. and Chrisman, J.J. (2016) 'Does size matter? The moderating effects of firm size on the employment of nonfamily managers in privately held family SMEs', Entrepreneurship: Theory \& Practice, Vol. 40, No. 5, pp.1017-1039.

Fryges, H. and Wagner, J. (2010) 'Exports and profitability: first evidence for German manufacturing firms', World Economy, Vol. 33, No. 3, pp.399-423.

Gallucci, C., Santulli, R. and Calabro, A. (2015) 'Does family involvement foster or hinder firm performance? The missing role of family-based branding strategies', Journal of Family Business Strategy, Vol. 6, No. 3, pp.155-165.

Galvan, R.S., Martinez, A.S. and Rahman, M.A. (2017) 'Impact of family business on economic development: a study of Spain's family-owned supermarkets', Journal of Business and Economics, Vol. 5, No. 12, pp.243-259.

Geroski, P.A. (1995) 'What do we know about entry?', International Journal of Industrial Organization, Vol. 13, No. 4, pp.421-440.

Girma, S., Greenaway, D. and Kneller, R. (2004) 'Does exporting increase productivity? A microeconometric analysis of matched firms', Review of International Economics, Vol. 12, No. 5, pp.855-866.

Golas, Z. (2011) 'SME sector economic position in the EU: insights into labor efficiency and profitability', Acta Scientiarum Polonorum. Oeconomia, Vol. 10, No. 3, pp.25-38.

Gómez-Mejía, L.R., Haynes, K.T., Núñez-Nickel, M., Jacobson, K.J.L. and Moyano-Fuentes, J. (2007) 'Socioemotional wealth and business risk in family controlled firms: evidence from Spanish olive oil mills', Administrative Science Quarterly, Vol. 52, No. 1, pp.106-137.

Gómez-Mejía, L.R., Núñez-Nickel, M. and Gutierrez, I. (2001) 'The role of family ties in agency contracts', Academy of Management Journal, Vol. 44, No. 2, pp.81-95.

Gonzalez, V.M. (2013) 'Leverage and corporate performance: international evidence', International Review of Economics \& Finance, Vol. 25, No. C, pp.169-184.

Greer, C.R., Carr, J.C. and Hipp, L. (2016) 'Strategic staffing and small-firm performance', Human Resource Management, Vol. 55, No. 4, pp.741-764.

Guarascio, D., Pianta, M. and Bogliacino, F. (2016) 'Export, R\&D and new products. A model and a test on European industries', Journal of Evolutionary Economics, Vol. 26, No. 4, pp.869-905.

Hall, A., Melin, L. and Nordqvist, M. (2001) 'Entrepreneurship as radical change in the family business: exploring the role of cultural patterns', Family Business Review, Vol. 14, No. 3, pp.193-208.

Hatak, I., Kautonen, T., Fink, M. and Kansikas, J. (2016) 'Innovativeness and family-firm performance: the moderating effect of family commitment', Technological Forecasting and Social Change, Vol. 102, No. C, pp.120-131.

Hecht, J. (2008) 'Modelling cross-sectional profitability and capital intensity using panel corrected significance tests', Applied Financial Economics, Vol. 18, No. 18, pp.1501-1513. 
Hovakimian, A., Opler, T. and Titman, S. (2001) 'The debt-equity choice', Journal of Financial and Quantitative Analysis, Vol. 36, No. 1, pp.1-24.

Isik, O. (2017) 'Determinants of profitability: Evidence from real sector firms listed in Borsa Instanbul', Business \& Economics Research Journal, Vol. 8, No. 4, pp.689-698.

Jovanovic, B. (2001) 'Fitness and age-Review of Carroll and Hannan's demography of corporations and industries', Journal of Economic Literature, Vol. 39, No. 1, pp.105-124.

Kachaner, N., Stalk, G. and Bloch, A. (2012) 'What you can learn from family business', Harvard Business Review, Vol. 90, No. 11, pp.102-106.

Kane, A., Marcus, A.J. and McDonald, R.L. (1985) 'Debt policy and rate of return premium to leverage', Journal of Financial \& Quantitative Analysis, Vol. 20, No. 4, pp.479-499.

Kazempour, M. and Aghaei, M.A. (2015) 'Capital structure and firms performance in Tehran Stock Exchange', International Journal of Management, Accounting \& Economics, Vol. 2, No. 2, pp.149-152.

Kim, Y. and Gao, F.Y. (2013) 'Does family involvement increase business performance? Family longevity goals' moderating roles in Chinese family firms', Journal of Business Research, Vol. 66, No. 2, pp.265-274.

Kneller, R. and Pisu, M. (2010) 'The returns to exporting: Evidence from UK firms', Canadian Journal of Economics, Vol. 43, No. 2, pp.494-519.

Kogut, B. and Zander, U. (1992) 'Knowledge of the firm, combinative capabilities, and the replication of technology', Organization Science, Vol. 3, No. 3, pp.383-397.

König, A., Kammerlander, N. and Enders, A. (2013) 'The family innovator's dilemma: how family influence affects the adoption of discontinuous technologies by incumbent firms', Academy of Management Review, Vol. 38, No. 3, pp.418-441.

Kotlar, J., De Massis, A., Frattini, F., Bianchi, M. and Fang, H. (2013) 'Technology acquisition in family and nonfamily firms: a longitudinal analysis of Spanish manufacturing firms', Journal of Product Innovation Management, Vol. 30, No. 6, pp.1073-1088.

Kotlar, J., Fang, H., De Massis, A. and Frattini, F. (2014) 'Profitability goals, control goals, and the R\&D investment decisions of family and nonfamily firms', Journal of Product Innovation Management, Vol. 31, No. 6, pp.1128-1145.

Lang, L.P. and Stulz, R.M. (1994) 'Tobin's q, corporate diversification, and firm performance', Journal of Political Economy, Vol. 102, No. 6, pp.1248-1279.

Larimo, J. (2013) 'Small and medium-size enterprise export performance', International Studies of Management \& Organization, Vol. 43, No. 2, pp.79-100.

Laursen, K. and Salter, A. (2006) 'Open for innovation: the role of openness in explaining innovation performance among UK manufacturing firms', Strategic Management Journal, Vol. 27, No. 2, pp.131-150.

Lawless, M., O'Connell, B. and O'Toole, C. (2015) 'Financial structure and diversification of European firms', Applied Economics, Vol. 47, No. 23, pp.2379-2398.

Lee, J. and Hall, Jr. E. (2008) 'An empirical investigation of the 'Halo' effect of financial performance on the relationships between corporate reputation and CEO compensation', American Journal of Business Research, Vol. 1, No. 1, pp.93-110.

Lee, S. and Xiao, Q. (2011) 'An examination of the curvilinear relationship between capital intensity and firm performance for publicly traded US hotels and restaurants', International Journal of Contemporary Hospitality Management, Vol. 23, No. 6, pp.862-880.

Lee, S., Park, G., Yoon, B. and Park, J. (2010) 'Open innovation in SMEs - an intermediated network model', Research Policy, Vol. 39, No. 2, pp.290-300.

Leitch, P. and Lamminmaki, D. (2011) 'Refining measures to improve performance measurement of the accounts receivable collection function', Journal of Applied Management Accounting Research, Vol. 92, No. 2, pp.1-20.

Leonard-Barton, D. (1992) 'Core capabilities and core rigidities: a paradox in managing new product development', Strategic Management Journal, Vol. 13, No. S1, pp.111-125. 
Levesque, M. and Minniti, M. (2006) 'The effect of aging on entrepreneurial behavior', Journal of Business Venturing, Vol. 21, No. 2, pp.177-194.

Lewis, R. and Reiley, D. (2014) 'Advertising effectively influences older users: how field experiments can improve measurement and targeting', Review of Industrial Organization, Vol. 44, No. 2, pp.147-159.

Li, F. and Srinivasan, S. (2011) 'Corporate governance when founders are directors', Journal of Financial Economics, Vol. 102, No. 2, pp.454-469.

Li, L. and Zhu, B. (2015) 'Family involvement, firm size, and performance of private-owned enterprises', The Journal of Chinese Sociology, Vol. 2, No. 11, pp.1-18.

Liao, T. and Lin, W. (2017) 'Corporate governance, product market competition, and the wealth effect of R\&D spending changes', Financial Management, Vol. 46, No. 3, pp.717-742.

López-Gracia, J. and Sánchez-Andújar, S. (2007) 'Financial structure of the family business: evidence from a group of small Spanish firms', Family Business Review, Vol. 20, No. 4, pp.269-287.

Lu, J.W., Liang, X., Shan, M. and Liang, X. (2015) 'Internationalization and performance of Chinese family firms: the moderating role of corporate governance', Management \& Organization Review, Vol. 11, No. 4, pp.645-678.

Lwango, A., Coeurderoy, R. and Gimenez Roche, G.A. (2017) 'Family influence and SME performance under conditions of firm size and age', Journal of Small Business and Enterprise Development, Vol. 24, No. 3, pp.629-648.

Ma, L., Ma, S. and Tian, G.G. (2017) 'Corporate opacity and cost of debt for family firms', The European Accounting Review, Vol. 26, No. 1, pp.27-59.

Madashetti, S. and Kibona, D. (2013) 'Impact of inventory management on the profitability of SMEs in Tanzania', International Journal of Research in Commerce \& Management, Vol. 4, No. 2, pp.1-5.

Makrini, H.E. (2015) 'Predictors of export performance in developing economies: a longitudinal analysis of Moroccan SMEs', Journal of Strategic Marketing, Vol. 25, No. 7, pp.530-546.

Malik, M.S. and Bukhari, M. (2014) 'The impact of working capital management on corporate performance: a study of firms in cement, chemical and engineering sectors of Pakistan', Pakistan Journal of Commerce \& Social Sciences, Vol. 8, No. 1, pp.134-148.

Marshall, P.J., Sorenson, R., Brigham, K., Wieling, E., Reifman, A. and Wampler, R.S. (2006) 'The Paradox for the family firm CEO: owner age relationship to succession related processes and plans', Journal of Business Venturing, Vol. 21, No. 3, pp.348-368.

Matzler, K., Veider, V., Hautz, J. and Stadler, C. (2015) 'The impact of family ownership, management, and governance on innovation', Journal of Product Innovation Management, Vol. 32, No. 3, pp.319-333.

Memili, E., Misra, K., Chang, E.P.C. and Chrisman, J.J. (2013) 'The propensity to use incentive compensation for non-family managers in SME family firms', Journal of Family Business Management, Vol. 3, No. 1, pp.62-80.

Michel, A. and Israel, S. (1984) 'Does business diversification affect performance?', Financial Management, Vol. 13, No. 4, pp.18-25.

Miller, D. and Le Breton-Miller, I. (2006) 'Family governance and firm performance: agency, stewardship, and capabilities', Family Business Review, Vol. 19, No. 1, pp.73-87.

Miller, D. and Shamsie, J. (2001) 'Learning across the life cycle: experimentation and performance among the Hollywood studio heads', Strategic Management Journal, Vol. 22, No. 8, pp.725-745.

Minetti, R., Murro, P. and Zhu, S.C. (2015) 'Family firms, corporate governance and export', Economica, Vol. 82, No. 1, pp.1177-1216.

Moser, P., Isaksson, O.H. and Seifert, R.W. (2017) 'Inventory dynamics in process industries: an empirical investigation', International Journal of Production Economics, Vol. 191, No. C, pp.253-266. 
Ngo, L.V. and O'Cass, A. (2012) 'Performance implications of market orientation, marketing resources, and marketing capabilities', Journal of Marketing Management, Vol. 28, Nos. 1-2, pp.173-187.

Nguyen, T.V., Le, N.T. and Bryant, S.E. (2013) 'Sub-national institutions, firm strategies, and firm performance: a multilevel study of private manufacturing firms in Vietnam', Journal of World Business, Vol. 48, No. 1, pp.68-76.

Nikolov, A.N. (2017) 'Family ownership, advertising, and R\&D: implications for firm performance', International Interdisciplinary Business-Economics Advancement Journal, Vol. 2, No. 2, pp.65-80.

Pakes, A. and Ericson, R. (1998) 'Empirical implications of alternative models of firm dynamics', Journal of Economic Theory, Vol. 79, No. 1, pp.1-46.

Park, A., Dean, Y., Xinzheng, S. and Yuan, J. (2010) 'Exporting and firm performance: Chinese exporters and the Asian financial crisis', Review of Economics \& Statistics, Vol. 92, No. 4, pp.822-842.

Pérez-Cabañero, C., González-Cruz, T. and Cruz-Ros, S. (2012) 'Do family SME managers value marketing capabilities' contribution to firm performance?', Marketing Intelligence \& Planning, Vol. 30, No. 2, pp.116-142.

Poza, E.J. (2007) Family Business, Thomson South-Western, New York.

Pucci, T., Simoni, C. and Zanni, L. (2015) 'Measuring the relationship between marketing assets, intellectual capital and firm performance', Journal of Management \& Governance, Vol. 19, No. 3, pp.589-616.

Romano, C.A., Tanewski, G.A. and Smyrnios, K.X. (2001) 'Capital structure decision making: a model for family business', Journal of Business Venturing, Vol. 16, No. 3, pp.285-310.

Sarkar, S., Hernández-Linares, R. and Cobo, M.J. (2014) 'Winnowing wheat from the chaff: the evolution of the family business concept', 74th Annual Meeting of the Academy of Management, Philadelphia, Pennsylvania, USA.

Sciascia, S., Nordqvist, M., Mazzola, P. and De Massis, A. (2015) 'Family ownership and R\&D intensity in small- and medium-sized firms', Journal of Product Innovation Management, Vol. 32, No. 3, pp.349-360.

Shanker, M. and Astrachan, J. (1996) 'Myths and realities: family businesses' contribution to the US economy, a framework for assessing family business statistics', Family Business Review, Vol. 9, No. 2, pp.107-119.

Shin, S., Ennis, K.L. and Spurlin, W.P. (2015) 'Effect of inventory management efficiency on profitability: current evidence from the U.S. manufacturing industry', Journal of Economics \& Economic Education Research, Vol. 16, No. 1, pp.98-106.

Sorensen, J. and Stuart, T. (2000) 'Aging, obsolescence and organizational innovation', Administrative Science Quarterly, Vol. 45, No. 1, pp.81-112.

Sridhar, S., Narayanan, S. and Srinivasan, R., (2014) 'Dynamic relationships among R\&D, advertising, inventory and firm performance', Journal of The Academy of Marketing Science, Vol. 42, No. 3, pp.277-290.

Steenkamp, J.M. and Fang, E. (2011) 'The impact of economic contractions on the effectiveness of R\&D and advertising: evidence from U.S. companies spanning three decades', Marketing Science, Vol. 30, No. 4, pp.628-645.

Stough, R., Welter, F., Block, J., Wennberg, K. and Basco, R. (2015) 'Family business and regional science-bridging the gap', The Journal of Family Business Strategy, Vol. 6, No. 4, pp.208-218.

Strebulaev, I.A. and Yang, B. (2013) 'The mystery of zero-leverage firms', Journal of Financial Economics, Vol. 109, No. 1, pp.1-23.

Sun, S. (2014) 'Foreign entry and firm advertising intensity: evidence from China', Review of Industrial Organization, Vol. 45, No. 1, pp.79-97. 
Tallman, S. and Li, J. (1996) 'Effects of international diversity and product diversity on the performance of multinational firms', The Academy of Management Journal, Vol. 39, No. 1, pp.179-196.

Teal, E.J., Upton, N. and Seaman, S.L. (2003) 'A comparative analysis of strategic marketing practices of high-growth U.S. family and non-family firms', Journal of Developmental Entrepreneurship, Vol. 8, No. 2, pp.177-195.

Tsao, S-M. and Lien, W-H. (2013) 'Family management and internationalization: the impact on firm performance and innovation', Management International Review, Vol. 53, No. 2, pp.189-213.

van Essen, M., Carney, M., Gedajlovic, E.R. and Heugens, P.P.M.A.R. (2014) 'How does family control influence firm strategy and performance? A meta-analysis of US publicly listed firms', Corporate Governance: An International Review, Vol. 23, No. 1, pp.3-24.

Venkatraman, N. and Ramanujam, V., (1986) 'Measurement of business performance in strategy research: a comparison of approaches', Academy of Management Review, Vol. 11, No. 4, pp.801-814.

Villalonga, B. and Amit, R. (2006) 'How do family ownership, control and management affect firm value?', Journal of Financial Economics, Vol. 80, No. 2, pp.385-417.

Villalonga, B. and Amit, R. (2010) 'Family control of firms and industries', Financial Management, Vol. 39, No. 3, pp.863-904.

Wang, L., Cheng, C., Tseng, Y. and Liu, Y. (2015) 'Demand-pull replenishment model for hospital inventory management: a dynamic buffer-adjustment approach', International Journal of Production Research, Vol. 53, No. 24, pp.7533-7546.

Wolff, J.A. and Pett, T.L. (2000) 'Internationalization of small firms: an examination of export competitive patterns, firm size, and export performance', Journal of Small Business Management, Vol. 38, No. 2, pp.34-47.

Yildirim, N. (2015) 'Not leverage but change in leverage matters for firms' future growth: evidence from Turkey's Top 1000', International Economic Journal, Vol. 29, No. 3, pp.503-525.

Zahra, S.A. (2012) 'Organizational learning and entrepreneurship in family firms: exploring the moderating effect of ownership and cohesion', Small Business Economics, Vol. 38, No. 1, pp.51-65.

Zainudin, N. and Regupathi, A. (2010) 'Manufacturing SMEs' credit collection period and its determinants: some evidence from Malaysia', Folia Oeconomica Stetinensia, Vol. 9, No. 1, pp.83-104.

Zelgalve, E. and Berzkalne, I. (2015) 'The impact of debt ratios on corporate financial performance: the case of Baltic listed companies', Applied Economics: Systematic Research, Vol. 9, No. 1, pp.107-125. 